Please do not remove this page

RMIT

UNIVERSITY

\title{
Vulnerability to bushfires in rural Australia: a case study from East Gippsland, Victoria
}

Whittaker, Joshua; Handmer, John; Mercer, David

https://researchrepository.rmit.edu.au/esploro/outputs/9921858370101341/filesAndLinks?institution=61RMIT_INST\&index=null

Whittaker, J., Handmer, J., \& Mercer, D. (2012). Vulnerability to bushfires in rural Australia: a case study from East Gippsland, Victoria. Journal of Rural Studies, 28(2), 161-173.

https://doi.org/10.1016/j.jrurstud.2011.11.002

Document Version: Accepted Manuscript

Published Version: https://doi.org/10.1016/j.jrurstud.2011.11.002

Repository homepage: https://researchrepository.rmit.edu.au

(c) 2011 Elsevier Ltd. All rights reserved.

Downloaded On 2023/04/26 11:11:48 +1000

Please do not remove this page 
Thank you for downloading this document from the RMIT Research Repository.

The RMIT Research Repository is an open access database showcasing the research outputs of RMIT University researchers.

RMIT Research Repository: http://researchbank.rmit.edu.au/

\section{Citation:}

Whittaker, J, Handmer, J and Mercer, D 2012, 'Vulnerability to bushfires in rural Australia: a case study from East Gippsland, Victoria', Journal of Rural Studies, vol. 28, no. 2, pp. 161-173.

See this record in the RMIT Research Repository at:

http://researchbank.rmit.edu.au/view/rmit:15339

Version: Accepted Manuscript

Copyright Statement: (c) 2011 Elsevier Ltd. All rights reserved.

Link to Published Version:

http://dx.doi.org/10.1016/j.jrurstud.2011.11.002

\section{PLEASE DO NOT REMOVE THIS PAGE}




\section{Elsevier Editorial System(tm) for Journal of Rural Studies}

Manuscript Draft

Manuscript Number: RURAL-D-10-00202R1

Title: Vulnerability to bushfires in rural Australia: a case study from East Gippsland, Victoria

Article Type: Research Paper

Keywords: Vulnerability; disaster; rural; bushfire; wildfire; livelihoods; community.

Corresponding Author: Dr Joshua Whittaker,

Corresponding Author's Institution: RMIT University

First Author: Joshua Whittaker

Order of Authors: Joshua Whittaker; John Handmer; David Mercer

Abstract: This paper investigates the nature and causes of vulnerability to bushfires in the Wulgulmerang district of East Gippsland, Victoria, in south-eastern Australia. In 2003 bushfires devastated the small population of this isolated farming district, destroying homes, agricultural assets and public infrastructure. The fires also adversely affected the health, livelihoods and social lives of many local people. The paper examines: (i) how and why people were exposed to hazards during the bushfires; and (ii) how and why people were differentially capable of coping and adapting to the fires' impacts. Qualitative methods were primarily used to investigate these questions, including semistructured interviews with residents and landholders of the district and others who responded to the fires in an official or unofficial capacity. Vulnerability is shown to arise from the circumstances of people's everyday lives, which are shaped by factors both within and beyond their control. Local pressures and challenges - such as drought, declining farm incomes, depopulation, and the inaccessibility of essential services - are shown to increase people's exposure to hazards and reduce their capacities to cope and adapt. The paper demonstrates the fundamental importance of sustainable livelihoods and regional economic vitality to the long-term goal of vulnerability reduction. 
Vulnerability to bushfires in rural Australia: a case study from East Gippsland, Victoria

Joshua Whittaker ${ }^{1,3 *}$

John Handmer ${ }^{1,3}$

David Mercer $^{2}$

1: Centre for Risk and Community Safety, School of Mathematical and Geospatial Sciences, RMIT University, Melbourne, Australia

2: School of Global Studies, Social Science and Planning, RMIT University, Melbourne, Australia

3: National Climate Change Adaptation Research Facility (NCCARF), Australia

* Corresponding author

Phone: +61399252418

Fax: $\quad+61399252454$

Email: joshua.whittaker@gmail.com 


\title{
Vulnerability to bushfires in rural Australia: a case study from East Gippsland, Victoria
}

\begin{abstract}
:
This paper investigates the nature and causes of vulnerability to bushfires in the Wulgulmerang district of East Gippsland, Victoria, in south-eastern Australia. In 2003 bushfires devastated the small population of this isolated farming district, destroying homes, agricultural assets and public infrastructure. The fires also adversely affected the health, livelihoods and social lives of many local people. The paper examines: (i) how and why people were exposed to hazards during the bushfires; and (ii) how and why people were differentially capable of coping and adapting to the fires' impacts. Qualitative methods were primarily used to investigate these questions, including semi-structured interviews with residents and landholders of the district and others who responded to the fires in an official or unofficial capacity. Vulnerability is shown to arise from the circumstances of people's everyday lives, which are shaped by factors both within and beyond their control. Local pressures and challenges - such as drought, declining farm incomes, depopulation, and the inaccessibility of essential services - are shown to increase people's exposure to hazards and reduce their capacities to cope and adapt. The paper demonstrates the fundamental importance of sustainable livelihoods and regional economic vitality to the long-term goal of vulnerability reduction.
\end{abstract}

Key words:

Vulnerability; disaster; rural; bushfire; wildfire; livelihoods; community. 


\section{Introduction: The Wulgulmerang bushfire disaster}

On January 30, 2003, bushfires (or wildfires) triggered a major disaster in the Wulgulmerang district of East Gippsland, Victoria. Initially it was reported that six homes, the local service station, and a sports pavilion had been destroyed (Hodgson and Papadakis, 2003). However, it soon became apparent that the fires had wrought far greater damage and destruction, and that the long-term impacts on the district's small population would be profound. Three weeks later an article in Melbourne's The Age newspaper described the unfolding disaster (Miller, 2003). Thousands of sheep and cattle had been killed and more than twenty hay, wool and machinery sheds destroyed. With large sections of internal and boundary fencing missing, and little pasture or hay to feed surviving animals, many graziers were forced to reduce livestock numbers or accept the additional costs of buying feed or agistment. Wild dogs posed a further threat to stock, particularly sheep, as they ventured out from the surrounding national parks in search of prey. The fires had occurred in a context of longstanding drought, from which many graziers were still recovering. Local people complained that they had not received firefighting support and had been forgotten by government. 'Red tape' was said to be hampering recovery, with a roadblock sixty kilometres away said to be holding up deliveries of desperately needed hay and blocking insurance assessors, donated goods and outside support. This was a community 'feeling forgotten', 'hanging in there - just - thanks to the kindness of strangers', which would now have to 'wait and see what happens next' (Miller, 2003: 4).

This paper investigates vulnerability to bushfires in the Wulgulmerang district of East Gippsland, Victoria, in south-eastern Australia. It examines why the people of Gelantipy, Seldom Seen, Wulgulmerang, Black Mountain and Suggan Buggan ('the Wulgulmerang district') were so profoundly affected by the bushfires of January 30, 2003. Australian bushfire research has traditionally focused on the physical properties of fire hazards and 
disasters, with relatively little consideration of how cultural, economic, political and social factors shape vulnerability. This paper therefore contributes to the growing body of research that seeks to redress this imbalance (e.g. Gill, 1994; Whittaker and Mercer, 2004; Cottrell, 2005; Handmer and Haynes, 2008; Eriksen et al. 2010). It also seeks to contribute to the wider literature on economic and social change in rural places. Neoliberal policies that encourage economic deregulation, increased trade competitiveness, privatisation of stateowned assets and reduced government service provision (Tonts and Haslam-McKenzie, 2005) have undermined the social and economic sustainability of many towns and regions in rural Australia (Cocklin and Dibden, 2005). These changes have reduced the capacities of many rural communities to mitigate, cope with and recover from natural hazards such as drought and bushfires, as well as a range of other shocks and stresses.

This paper understands the causes and impacts of the Wulgulmerang disaster through the lens of human vulnerability. It examines factors that shaped people's exposure to hazards and their capacities for coping and adapting to impacts. Vulnerability is shown to arise from the circumstances of people's everyday lives (Eriksen and Gill, 2010), which are shaped by factors both within and beyond their control. Local pressures and challenges - such as drought, declining farm incomes, depopulation, and the inaccessibility of essential services are shown to increase people's exposure to hazards and reduce their capacities to cope and adapt. The paper demonstrates the fundamental importance of sustainable livelihoods and regional economic vitality to the long-term goal of vulnerability reduction.

\section{Vulnerability to environmental hazards}

\subsection{Environmental hazards}


Environmental hazards arise from the interaction of natural and social systems. Hazards are distinguished from 'extreme' events or processes in nature, which are not necessarily hazardous to people (Burton et al., 1978). Although environmental processes and events such as bushfires are often referred to as 'hazards', they are only hazards when they threaten human life, assets or other values we want to protect (Hewitt, 1997). This perspective recognises the benefits environmental processes provide, as well as the fact that hazards are often created when people occupy locations or engage in activities to exploit those benefits and resources (Burton et al., 1993). Conversely, hazards may be created where people are compelled by social, economic or political circumstances to occupy locations or engage in land uses and activities where potentially harmful processes and events may occur (Mustafa, 1998).

Geographical hazards research has historically focused on the range of human responses to environmental hazards. In their influential text, The environment as hazard, Burton et al. (1993: 31) proposed that human responses to hazards could be explained by examining 'the ways in which people (1) recognize and describe a hazard, (2) consider how they might deal with it, and (3) choose among the actions that seem to them available'. In this view, hazard response is first and foremost a matter of perception - both of hazards and of opportunities to 'adjust'. Consequently, hazards research has been strongly influenced by psychological theories of perception and decision-making (Kasperson and Dow, 1993). A number of studies have adopted this approach to understand individual perceptions and responses to wildfire hazards (Winter and Fried, 2000; McCaffrey, 2004; Martin et al., 2009).

A theoretical turn in human geography during the 1970s and 1980s (see Peet and Thrift, 1989) sparked sustained critique of natural hazards research. Research was shown to reduce 
complex human behaviour to individual perceptions and decisions, failing to take account of the social, economic and political contexts in which people act, and the myriad of factors that enable and constrain individual action (Ball, 1975; O'Keefe et al., 1976; Waddell, 1977; Torry, 1979; Walker, 1979; Hewitt, 1980; Watts, 1983; Hewitt, 1983). These critiques laid the foundation for a radically different approach to hazards and disaster research. Increasingly, researchers examined the role of social, political and economic systems in creating hazards, and in influencing - often undermining - people's capacities to protect themselves, cope and adapt.

\subsection{Human vulnerability}

In the contemporary social sciences, the causes and impacts of environmental hazards and disasters are understood primarily through concepts of human vulnerability and resilience. The meaning and usage of these terms are highly varied, even within disciplines. In the context of global environmental change, 'vulnerability' has been used to refer to characteristics of individuals, societies, ecosystems, technological systems, and a range of other social and ecological units (Dow, 1992). The term has also been used to describe characteristics of buildings, infrastructure, livelihoods, settlement locations, regions and economies (Wisner et al., 2004). Some have suggested that the language of vulnerability is disempowering, and are careful to define vulnerability as a process or social space rather than a status (Watts and Bohle, 1993; Pelling, 2003), or emphasise people's capacities and resiliencies (Hewitt, 1997; Handmer, 2003; Fordham, 2004). Despite the diversity of perspectives on vulnerability and resilience, all share a common concern: the susceptibility of human beings to harm from events, processes and changes in their physical and social environments. Research de-naturalises hazards and disasters by demonstrating that their causes are inherently social, and their impacts socially differentiated. 
Nevertheless, vulnerability and resilience are different concepts with different ways of framing human-environment interactions (Miller et al., 2010). The ecological origins of resilience (e.g. Holling, 1973) are reflected in recent research on the resilience of socialecological systems (e.g. Berkes and Folke, 1998; Folke, 2006; Walker and Westley, 2011). Concepts of vulnerability, as used in hazards and disaster research, emerged from a broader range of disciplines and perspectives in the social sciences, most notably hazards geography and anthropology (e.g. Hewitt, 1983). In this tradition, we employ a concept of vulnerability to understand the causes and impacts of the Wulgulmerang bushfire disaster. This concept of vulnerability entails two fundamental components that must be examined: (i) hazard exposure; and (ii) coping and adaptive capacities.

\section{Hazard exposure}

Hazard exposure is fundamental to vulnerability, since people can only be vulnerable in relation to a specific impact or set of impacts (Kelly and Adger, 2000). It is ultimately concerned with people's locations and activities relative to harmful environmental processes or events. As such, social scientists often assume that exposure is a matter for physical scientists, involving technical assessments of magnitudes, frequencies, probabilities and other hazard characteristics (Dow, 1992). However, any investigation of hazard exposure also requires analysis of how natural and social systems interact to put people at risk. This point is well made by Mustafa (1998: 290), who notes that 'Exposure is a function of the socially determined physical location of the communities at risk, as well as the human decisions and societal structures that imperil the community'. 
Social science research confirms that the powerless and marginalised often inhabit the most hazardous locations, are compelled to engage in hazardous livelihood strategies, and receive the least protection from the state (Cannon, 2000; Pelling, 2003; Wisner et al., 2004). However, all people are exposed to hazards in the courses of their everyday lives. For instance, many high bushfire risk areas have experienced population growth as people move away from metropolitan areas for the amenity and lifestyle of coastal and rural settings (Burnley and Murphy, 2004; Costello, 2007). Reduced housing affordability within inner Melbourne (Yates, 2008; Wood et al., 2008) has also encouraged residential development and population growth in high bushfire risk areas. Hazard exposure, then, is more properly viewed as a 'social' process through which people are exposed to potentially harmful processes or events.

\section{Coping and adaptive capacities}

Human capacities for response, coping, recovery and adaptation are a vital component of vulnerability. In Timmerman's (1981) early formulation, vulnerability is defined in terms of a system's potential to react adversely to the occurrence of a hazardous event. The type and extent of adverse reaction is said to be conditioned by the system's resilience - a measure of its capacity to absorb and recover from the impact of a hazardous event. More recent concepts of vulnerability highlight the active capacities of people, rather than systems. Here, Wisner et al.'s (2004: 11) definition is paramount: 'By vulnerability we mean the characteristics of a person or group and their situation that influence their capacity to cope with, resist and recover from the impact of a natural hazard'. Similarly, Hewitt $(1997 ; 1998)$ argues that vulnerability exists where people's capacities to avoid, resist or recover from harm are undermined by forces of social organisation. 
Nested within capacity-focused concepts of vulnerability are concepts of coping or adaptive capacity. 'Adaptive capacity' is commonly used in climate change research to refer to 'the ability or capacity of a system to modify or change its characteristics or behaviour so as to cope better with existing or anticipated external stresses' (Adger et al., 2004: 34). As this paper is ultimately concerned with people, adaptive capacity is used to refer to people's capacities to adapt to new circumstances triggered by their experience of a hazard or disaster.

Capacity-focused concepts of vulnerability often take hazard exposure as a given (Cutter, 1996); that is, while vulnerability implies exposure, exposure is formally outside the concept (Kelly and Adger, 2000). Consequently, analyses aim to identify factors that enable or constrain people's capacities to cope and adapt, but may not fully investigate how inequalities and injustices lead to greater hazard exposure for particular groups and individuals.

\section{Our approach}

The position taken in this paper is that concepts and analyses of vulnerability must explicitly account for people's exposure to hazards and their capacities for coping and adapting to hazard impacts. Numerous authors have conceptualised vulnerability in this way. Chambers (1989: 1), for example, defines vulnerability as 'exposure to contingencies and stress, and difficulty coping with them'. For Chambers, a household's exposure to contingencies and stress represents the 'external' dimension of vulnerability, while the lack of means to cope without damaging loss is the 'internal' dimension. In reality, hazard exposure and coping/adaptive capacities are shaped by factors both within and outside an individual or household's control (both internal and external factors). This is captured by Bohle et al. (1994: 37-38 \& 39): 
Vulnerability is best defined as an aggregate measure of human welfare that integrates environmental, social, economic and political exposure to a range of potential harmful perturbations... [It is] a multilayered and multidimensional social space defined by the determinate political, economic and institutional capabilities of people in specific places at specific times (emphasis added).

By defining vulnerability in terms of human welfare, Bohle et al. (1994) acknowledge that hazard exposure and coping/adaptive capacities are latent features of everyday life, taking their exact form at specific places and times with the impacts of particular hazardous processes or events. Furthermore, vulnerability is defined as a social space, rather than an ongoing condition or state, which people may move in and out of over space and time. In the analysis that follows, vulnerability is defined as a spatially and temporally contingent social space wherein people differentially experience heightened exposure to hazards and a diminished capacity to cope and adapt to impacts.

\section{Methodology}

The research aimed to investigate the nature and causes of vulnerability to bushfires in the Wulgulmerang district by examining local people's exposure to hazards and their capacities for coping and adapting to the fires' impacts. Qualitative methods were particularly appropriate due to the exploratory nature of the study. Data were gathered using a range of techniques including informal discussions and participant observations, semi-structured interviews with affected households, and archival research.

Semi-structured interviews were conducted three years after the fires with 39 residents and landholders of the district and 24 others who responded to the fires in an official or unofficial 
capacity. Names of potential interviewees were identified from public documents such as newspaper reports and submissions to post-bushfire inquiries, and from local contacts made on an initial fieldwork visit. Postal addresses and telephone numbers were obtained for most of these people using the local telephone book. A letter of invitation was sent to each household and landholder to explain the purpose of the research, followed by a telephone call to personally invite their participation. An interview guide, comprising eight open-ended questions, was developed to explore local people's vulnerability to, and experiences of, the fires. These questions (see Whittaker, 2008) investigated: households' preparedness for bushfires; how individuals, households and the community responded; how people and livelihoods were affected; causes of the disaster; and how bushfires, emergencies and disasters could be better managed in the future. Interviewees were also asked about everyday life in the district in order to develop an understanding of the context in which the fires occurred and to identify underlying factors that may have contributed to their vulnerability. The semi-structured interviews were guided by the principle that 'the participant's perspective on the phenomena of interest should unfold as the participant views it... not as the researcher views it' (Marshall and Rossman, 2006: 101). Accordingly, the interview questions were used to guide discussions, which were framed and structured by interviewees. Interviews were usually conducted in people's homes or elsewhere on their properties, typically lasting for 1-2 hours. Representatives of a range of organisations were also interviewed, including fire and emergency services, government departments, local community groups, and numerous volunteer and charitable organisations. Questions focused on their role in responding to the bushfires and their aftermath, factors influencing local vulnerability, and their observations of coping and adaptation. All of the interviews were digitally recorded and transcribed with each participant's informed consent. 
Participant observation played a minor but important role in the research. Opportunities for observing participants outside of the interview setting were limited due to the lack of public space in the district, which meant that people spent most of their time on their own properties. Nevertheless, occasions such as community meetings and cattle sales provided some opportunities for observation. Most valuable, however, were the meals shared with local people in their homes, where informal discussions provided opportunities to learn about their day-to-day lives. Local histories and historical records were another important data source, providing valuable information about the settlement and development of the district, demographic characteristics, and the many pressures and challenges local people face.

The interviews generated a large amount of data, which was managed and analysed using the computer software NVivo 7 (Bazely, 2007). The analysis aimed to identify the ways in which residents and landholders were exposed to bushfire hazards on January 30, 2003, and how they coped and adapted to the fires' impacts. A 'general inductive' approach to analysis was taken, with general categories developed from research aims and questions and more specific categories emerging from multiple interpretations of the raw data (Thomas, 2006). Analysis began with a close reading of the transcripts and the development of a list of potential categories into which segments of interview text could be grouped to enable closer analysis and comparison. For example, 'Impacts' was an initial category that, through the process of coding, was refined to include sub-categories for information on: direct losses; financial and livelihood impacts; physical and psychological health impacts; social impacts; and environmental impacts. The iterative process of coding led to the creation of categories that more accurately reflected the content of the interview transcripts, allowing important issues and themes to be identified and data to be more closely analysed (Bazely, 2007). 


\section{The Wulgulmerang district}

[Figure 1 about here]

The Wulgulmerang district is a remote farming region situated between the Alpine and Snowy River National Parks in East Gippsland, Victoria. With a population of less than 100 permanent residents, it takes in the small settlements of Gelantipy, Seldom Seen, Wulgulmerang, Black Mountain and Suggan Buggan (see Figure 1). The local economy is sustained by cattle and sheep farming. The small settlements that make up the district are not towns; from the main road one mostly sees farmland and a few houses and sheds surrounded by dense, native vegetation. There is very little communal space, save for a public hall at Gelantipy, a sports pavilion at Wulgulmerang, and thousands of hectares of mostly forested public land. There are two fuel stops, but no other shops, post offices, banks or hotels. The district is one of the few parts of Victoria, a relatively densely settled State, classified as 'remote' under the Accessibility/Remoteness Index of Australia (ARIA).

Like many rural Australian towns and regions, the district currently faces a range of social and economic challenges. The accelerated rate of change in rural Australia since the 1970s has been attributed to the neo-liberal turn in Australian politics, which saw progressive deregulation of the agricultural sector and the demise of socio-spatial equity as a basic principle of public policy (Lawrence, 1987; Tonts, 2000). Declining farm incomes, property amalgamations and enlargements, and the out-migration of agricultural workers and their families have undermined the social and economic vitality of many small towns, which have tended to experience a contraction of local economic activity, rising unemployment, withdrawal of services, depopulation, and a breakdown of local institutions and networks 
(Tonts, 2000). Residents and landholders of the Wulgulmerang district contend with many of these challenges on a daily basis. In addition, since the mid-1990s most of Victoria had experienced severe drought conditions, characterised by the lowest streamflow in approximately 80 years of record (Kiem and Verdon-Kidd, 2010). The social and economic impacts of the 'Big Dry' were particularly severe for farming families and rural communities (Alston and Kent, 2008), including in the research area.

\subsection{Climatic variability}

Climatic variability exerts a strong influence on lives and livelihoods in the district. The climate is mild, with average maximum temperatures of $21-23^{\circ} \mathrm{C}$ in summer and $9-12^{\circ} \mathrm{C}$ in winter. ${ }^{1}$ On average, there are 11 days each year when temperatures exceed $30^{\circ} \mathrm{C}$ and 16 days below $0^{\circ} \mathrm{C}$. Average rainfall in Gelantipy is $727.3 \mathrm{~mm}$, which is relatively evenly distributed throughout the year. Differences in topography, however, mean that Gelantipy receives more rainfall than Wulgulmerang and Black Mountain, the other main farming settlements. The latter are often exposed to more severe winters due to their elevation. Low temperatures and occasional snowfalls can prevent grass growth, forcing some graziers to relocate livestock to properties owned or leased in the lower country.

Local graziers also contend with considerable climatic variability. The highest annual rainfall on record is $1190 \mathrm{~mm}$ in 1966, compared to a low of 516mm in 1977. Between 1962 and 1975 the average annual rainfall at Gelantipy was $881 \mathrm{~mm}$, compared to just $728 \mathrm{~mm}$ between 1995 and 2007. Very low rainfall in 1997/98 decimated livestock throughout the district. A lack of pasture and high prices for feed saw a glut of cattle and 20-year low prices (Gleeson et al., 2003). The 1997 Asian economic crisis also contributed to a $22 \%$ fall in the value of Australia's live cattle exports, placing further strain on beef producers (ABS, 2005). At 
Wulgulmerang, an elderly grazing couple estimated that it cost AUD 75,000 in 1998 to feed their cattle and sheep through the drought. Eight years later, they were yet to recover:

We're still under [government] drought assistance. And if it wasn't for the drought assistance a lot of us would not be here, put it that way... It's just hand to mouth.

$$
\text { Maureen, Wulgulmerang }{ }^{2}
$$

\subsection{Livelihoods and the local economy}

The district's lack of economic diversity and dependence on cattle and sheep farming means that it is highly vulnerable to shocks and crises in the agricultural sector. Australian farmers have experienced declining terms of trade since the 1970s, when economic protections for agricultural exports were dismantled and producers were exposed to competition with highly subsidised producers in world markets (Lawrence, 1987). In 2005, Australia provided the second lowest level of support to agriculture of all OECD countries (Productivity Commission, 2005). To remain competitive, farmers have increased efficiency by enlarging their operations and reducing inputs. Restructuring in the district has seen farm enlargements, amalgamations and a reduction in opportunities for employment on farms, as well as in businesses that service the agricultural sector. The pursuit of economic efficiency at the individual farm level has undermined the social and economic viability of the district as a whole by creating unemployment and fuelling out-migration, which has seen reduced demand for local goods and services, the closure of local businesses, withdrawal of services, and diminished opportunities for social and cultural interaction. 
Our biggest problem, as far as the farm economics side of things is concerned, really goes back to [former Prime Minister] Whitlam. ${ }^{3} \mathrm{He}$ wanted to get at the 'Collins Street Farmers', ${ }^{4}$ so he tried to make sure that all the tax advantages there were with farming were taken out. He took out all those bigger people and, by doing that, he took out fencing contractors and all these guys that used to work on those properties... We started to get this drain of people leaving, until we got to a stage where only the people that owned the place were working the place... And of course, there used to be enough money in the area that people would stop and play sport and things on the weekend... But because people don't have the time anymore we've all got that much pressure on us now - we're all working seven days a week. And that's an economic thing, but it comes down to social fabric.

Dennis, Gelantipy

Also contributing to out-migration and community decline is an increase in the number of large, absentee landholdings. A local grazier estimated that 12 or 14 families once lived and farmed a 4500 ha area that is now owned and operated by one absentee landholder.

The decline of sheep farming has placed further strain on local livelihoods. Some graziers claim that predation by wild dogs has forced them out of sheep farming, alleging that government departments have failed to control dogs on public land. An outbreak of Ovine Johne's Disease (OJD) in 1998 also decimated sheep flocks, leading to greater dependence on cattle to sustain livelihoods. 
Changes to livelihoods and the local economy have transformed the district's social landscape. The most visible change is the aged and diminished state of the local population; in 2003 there were less than 100 residents. Interviewees described the ongoing exodus of young people and the subsequent ageing of the remaining population, a trend evident in many parts of rural Australia (Hugo, 2005). Amenity-led in-migration (Argent et al., 2010) has also occurred, albeit on a very small scale and mostly involving part-time or seasonal residents. Educational opportunities have always been limited, with only primary-level schooling available. Secondary students commonly travel to and from schools more than 100km away, or attend boarding schools. However, in 2001 the local primary school closed due to insufficient enrolments, forcing a number of families to leave the district.

The main thing affecting a community like this is the shrinking population. A lot of the things that used to bring the community together are diminished or don't exist anymore... It's one of those things with rural Australia: farming demands bigger and more efficient farms. So unless there's an independent influx, some other industry, some other reason to populate the area, it's just going to keep losing facilities... The school's gone. The services that are here are underused and subsidised. So I don't know where it goes from here. I don't know how it can be built back up to that sort of population again.

\section{Gary, Seldom Seen}

The closure of the local school was widely regarded as a 'tipping point' for the local community, as it will be difficult to attract young families to the area without primary education. Residents also lament the loss of opportunities to socialise with others, particularly 
through local sporting clubs and events. Community life now largely revolves around participation in a declining number of local groups, organisations and committees. Volunteer fire brigades are historically important in many parts of rural and regional Australia (see Murray and White, 1995). The Gelantipy fire brigade, which comprises members from and serves the entire Wulgulmerang district, has struggled to retain members, with many of those who remain aged over 65 .

As is the case in many communities, ${ }^{5}$ people in the district do not always agree or get along. For as long as most interviewees could remember, community life had been marked by social divisions between particular families and individuals, but more generally between the northern and southern ends of the district. Although residents identify as belonging to the one community, these divisions manifest in a shared sense of identity and greater social interaction within each end of the district. Although many residents have good relations with people at both ends, these divisions are important to understanding the events of January 30 , 2003, and their aftermath.

\section{Vulnerability to the January 30 bushfires}

On January 8, 2003, lightning strikes from a dry thunderstorm ignited more than 80 fires in the predominantly forested and alpine areas of north-eastern Victoria and East Gippsland. Three weeks later, on January 30, fires swept through the Wulgulmerang district, causing extensive damage to homes, livelihoods and public infrastructure. This section discusses factors influencing people's exposure to hazards during the bushfires and their capacities for coping and adapting to impacts.

\subsection{Factors influencing hazard exposure}




\section{Human locations and land uses}

Bushfires have been a threat to human life and property in the district since settlement in the 1830s. Early settlers occupied the Wulgulmerang plateau to capitalise on its grazing resources, recognising that much of the region's vegetation had evolved with and was prone to fires of natural and anthropogenic origin. Regular burning of grasses and scrub improved pasture, but also promoted the succession of fire-tolerant (and flammable) species in some ecosystems (Wakefield, 1970). Private landholders continue to use fire to improve pasture and reduce fuels on their land, while government and land managers prescribe fire on public land to meet ecological and fuel management objectives (Gould, 2006).

Geographically, agriculture is the predominant land use that gives rise to bushfire hazard in the region. Agricultural properties comprise a range of assets that may be threatened by fires, including family homes and belongings, livestock, fodder, fences, sheds, equipment and stored produce. The broad distribution of these assets over large areas - exacerbated by the shift to larger, more productive farms - makes them difficult to prepare and defend, particularly given the diminishing population and limited local firefighting capacity. Many residential and holiday properties are located in high-amenity areas that are isolated, inaccessible and in close proximity to native vegetation. Bushfires are particularly hazardous at these properties due to the abundance of unmanageable fuels, the steep, narrow and poorly surfaced roads (which can become blocked by fallen trees) and because residents are less likely to receive neighbourly and firefighting support in these locations during fires.

These land uses gave rise to very different types and degrees of hazard exposure during the fires. Farmers and others who made their livelihood from their primary place of residence generally experienced greater hazard exposure. Residential and holiday homeowners 
potentially faced greater risks to life due to their high fire-risk locations; however, many of these residents left or stayed away from their properties during the fires. Residents in Suggan Buggan were advised that they would not receive firefighting support, as it would be too dangerous to send firefighters down the narrow, winding roads to the settlement. Insurance was a significant factor influencing these residents' decisions to leave or stay away from their properties.

We made the decision in the end that we were fully insured and - because we live on a bush block - we felt particularly vulnerable. In the end, we just decided that our lives were more important.

Gavin, Wulgulmerang

The district's farmers tend to inhabit lower (albeit still high) fire risk locations on the largely cleared plateau. However, typically they had a greater share of their asset base threatened and therefore more readily accepted the risks of staying to defend their properties and livelihoods. This was the case for farming men and women, who traditionally have had considerable involvement in fire management and firefighting.

It's not really an option [leaving]. We've got all our animals [livestock] and things that were probably considered almost part of the family... We never considered it.

Alan, Wulgulmerang

Consequently, not only are economic damages from bushfires disproportionately large for farming households (see also Niemi and Lee, 2001), they also face greater risks to life and 
health when, in their longer-term economic interests, they are compelled to stay and protect their livelihoods.

\section{Hazard mitigation - the state}

Hazard mitigation by the state is part of what Cannon (2000) refers to as 'societal' protection from hazards. Given that bushfire hazards result from the interaction of natural and social systems (Burton et al., 1993), there are two main mitigation strategies available to the state. First, governments may regulate land use to control or prevent development in areas that are subject to bushfires. This strategy attends to the 'social' component of bushfire hazard; that is, the human locations and land uses that create hazards. Second, they can manage the land to reduce the potential for destructive bushfires. This strategy addresses the 'natural' component of hazard through modification of the environmental conditions that create the potential for destructive fires. State and local governments employ both land use planning and land management strategies to mitigate bushfire hazards in Victoria.

Land use planning is the most effective strategy for preventing and mitigating hazards (Mileti, 1999). In Victoria, the use and development of land is regulated through a system of planning schemes established by the Planning and Environment Act 1987. One of the many objectives of the East Gippsland Planning Scheme (EGSC, 2007: clause 15.01-1) is 'To assist in the minimisation of risk to life, property, the natural environment and community infrastructure from wildfire'. The chief mechanism for achieving this objective is the 'Wildfire Management Overlay’ (WMO; Hughes and Mercer, 2008), which stipulates where development will be permitted and how it must occur to minimise risks to life and property. While parts of the Wulgulmerang district are covered by the WMO, its regulatory power can only be exercised for new developments or redevelopments of land. Most homes in the 
district pre-date these controls and, given the limited economic resources of many households, are unlikely to be rebuilt or substantially renovated in the near future. Furthermore, while there has been a small influx of people seeking residential amenity, the overall trend in recent decades has been one of depopulation and socio-economic decline, not 'development'. Consequently, while the WMO may protect against hazardous development in the future, it did not substantially mitigate bushfire hazard during the January 30 fires.

Most residents and landholders attributed their hazard exposure to the accumulation of fuels in national parks. There was a strong and widely-held belief that more regular and broad-scale fuel reduction would have prevented - or at least reduced - the damage caused by the fires.

All the bush country around us hadn't been fuel-reduced for years and years. We'd been at them for many years to do fuel reduction, and they more or less laughed at us and said: 'We can handle any fire that comes along'. We warned them that we'd be burnt out one day if they didn't do something and we were right unfortunately.

'Reg', Seldom Seen

While not a panacea for fire control, prescribed burning is the only practical way to reduce fuels over large areas, and may aid suppression by reducing the growth of a fire from its ignition point, the height of flames and rate of spread, the potential for spotting, and the total heat intensity of a fire (Gould, 2006). However, land managers and scientists generally agreed that extreme weather conditions negated any significant effects of previous prescribed burns. This is supported by the weight of scientific evidence, which suggests that the influence of fuel on fire behaviour diminishes as fire weather intensifies (see Fernandes and Botelho, 
2003; Bradstock et al., 2010). Indeed, fire behaviour scientists observed that very few previous fuel reduction burns were effective in slowing the spread of fires on January 18, 26 and 30, which were all days of 'Extreme' fire weather.

\section{Hazard mitigation - residents and landholders}

A range of strategies are available to residents and landholders to mitigate bushfire hazard on their properties (Webster, 1986; Schauble, 2004). These include strategic measures such as designing and situating homes to minimise exposure to flames and heat, as well as seasonal and 'last-minute' preparations like clearing flammable materials from around buildings and blocking downpipes and filling gutters with water. Although most homes pre-date bushfirerelated planning controls and were not designed to mitigate bushfire hazard, a small number of residents had made minor modifications, such as fitting sprinklers to the roof. General property maintenance formed the basis of most people's preparedness, with an intense period of preparatory activity occurring once it was clear that fires were threatening. The long lead up to the fires meant residents and landholders had ample forewarning and time to prepare.

Farmers were particularly well-equipped to defend assets, with many having specialised equipment or being able to adapt basic farm equipment for firefighting purposes. Given that financial pressures prevent many farmers from attaining specialised equipment, improvisation played a critical role in their preparedness. Farmers were also advantaged by their capacity to repair equipment that failed or was damaged during the fires.

Participation in non-local social networks was also an important determinant of preparedness. The broad distribution of assets across large farm properties and the small local population meant that most landholders sought help to prepare from beyond the district. Most organised 
visits from friends and relatives to help prepare and defend against the fires. Social networks were also used to access refuge for children, some of whom were sent away during the fires (ranging from days to weeks). Again, the long-lead up to the fires meant that there was sufficient time to make these arrangements and for help to arrive.

Volunteer firefighters suggested that most people were not prepared for the scale and severity of the fires. Despite claims that the events of January 30 constituted a 'firestorm' for which preparedness counted little, they maintained that most people could have done more to prepare themselves and their properties. Perceptions of adequate preparedness were formed on the basis of past experiences of smaller, more manageable fires.

We've all seen fires before and we're used to working with it. But nobody had ever seen anything like this before. It came through harder and faster than anybody had ever expected. I thought we'd have time to get from one place to another, but there was no time - it hit everybody at once. So I think people thought they'd be able to manage it when, in fact, it wasn't manageable... I'd say preparedness was reasonable, I wouldn't say it was terrific.

'Dennis', Seldom Seen

\section{Physical characteristics of the bushfires}

The severity of the January 30 fires can be partly attributed to the climatic conditions that preceded and extended into the summer of 2002/03, which saw severe rainfall deficiencies and above average temperatures throughout Victoria (Bureau of Meteorology, 2003a; 2007). The culmination of rainfall deficiencies, low atmospheric humidity and cloudiness, and high 
daytime temperatures resulted in the early curing of fuels throughout south-eastern Australia (Bureau of Meteorology, 2003a). While it is normal for fine fuels ( $<6 \mathrm{~mm}$ in diameter) to become well cured during summer, these conditions resulted in the curing of heavy fuels, which significantly increased the available fuel load (Taylor and Webb, 2005).

According to the Bureau of Meteorology (2003b, 20), January 30 was the most significant 'blow-up day' of the 2003 Victorian bushfires. The day was characterised by large fire runs, long-distance spotting and extreme fire behaviour throughout north-eastern Victoria and East Gippsland. By $11 \mathrm{am}$ temperatures in Gelantipy had reached $30^{\circ} \mathrm{C}$ and, after a north-westerly wind change at $11.19 \mathrm{am}$, rose to more than $33^{\circ} \mathrm{C}$ with winds gusting to $65 \mathrm{~km} / \mathrm{h}$. Strong winds drove fires through the Alpine National Park until, shortly before 2pm, embers began to land in Wulgulmerang, igniting spot fires. Fires burned with extreme intensity in forested areas with flame heights between 10 and 30 metres and fire intensities greater than 40,000kW/m. In the grasslands of the Plateau, flame heights ranged between one and three metres, with fire intensities of approximately 7,000kW/m (CFA and DSE, 2003). Fires burned throughout the district and at approximately $3.30 \mathrm{pm}$ a south-westerly wind change blew two runs together, causing extreme fire behaviour. The junction zone for these two fires was Seldom Seen, where a home and service station were destroyed. The wind change abated the spread of fires into Gelantipy; however, blazes continued further to the north.

I was sitting there in the paddock watching, and there was this big roar and everything went red. Then this fireball came out of Boundary Creek and headed for [a local grazier's] house, straight at it... And then, I don't know how long it was, five or ten minutes, the smoke lifted again and all I could 
see was that from Seldom Seen right through to Black Mountain - the whole lot was on fire.

'Rory', Wulgulmerang

Table 1 outlines physical characteristics of the fires that were particularly influential in shaping people's exposure to hazards.

[Table 1 about here]

\section{Household responses}

Household responses were largely consistent with the approach advocated at the time by Australian fire authorities: to prepare, stay and defend, or leave early (AFAC, 2005). Threequarters of households were attended during the fires and, where necessary, actively defended. Some residents opted to leave early or, in the case of seasonal or part-time residents, stayed away from their properties for the duration of the fires.

Residents commonly sheltered inside their homes during the main fire front, with most being able to defend their homes and other assets by fighting the fires immediately before and after. Three of the six houses that were destroyed were unattended, while three were inadequately defended or un-defendable due to their condition and poor preparation. These findings support the assertion that 'ordinary' people can successfully defend their homes from bushfires, provided they are physically and mentally prepared (Handmer and Tibbits, 2005; Haynes et al., 2010). ${ }^{6}$ People's capacities to defend livelihood assets, however, were more limited. Due to the scale of their properties and broad distribution of assets, most farmers 
concentrated their efforts on their home and assets in close proximity. Consequently, thousands of sheep and cattle, hundreds of kilometres of farm fences, sheds, and large quantities of pasture and hay were destroyed.

I couldn't see that far - there was so much smoke, so much noise... The light was like a welding light - blue light. The heat wasn't so noticeable, but the wind and debris [was]... The fire was veering around a little bit and so there was always a busy side and a quiet side [of the building]. So you could be in the quiet side and spray [water] from there, and then when it got too hot just duck around the other side and do it from there.

'Gary', Seldom Seen

Household responses didn't always go to plan. An elderly grazier, for example, undertook a late and potentially dangerous evacuation on the advice of a neighbour. He made it to the safety of a neighbouring property, but lost his home. In contrast, the early arrival of the fires prevented one couple from leaving early. Their high level of preparedness - they had sent their children to stay with friends and had meticulously prepared their property - meant that they were able to safely and successfully defend their home. More common were deviations from the informal plans that specified rules, roles and responsibilities for each member of the household. It is significant that people, mostly men, broke rules designed to ensure their safety - for example, by leaving the safety of the home and driving vehicles through smoke and flames - to protect livelihood assets. These attempts to protect assets were usually futile and greatly increased their hazard exposure.

\section{Firefighting/emergency response}


The Country Fire Authority (CFA) - one of the world's largest volunteer-based emergency management organisations - is the lead authority in Victoria for protecting people and private property from bushfires. During the January 30 fires, most local people did not receive firefighting support. Fire authorities had decided that, due to the 'Extreme' fire danger, volunteers would not be deployed into situations where their lives could be threatened. Regardless of whether this was the right decision - a matter that was debated intensely after the fires - it is clear that many local people experienced greater hazard exposure than would have been the case if they had received firefighting support.

Importantly, the aged and diminished state of the district's population meant that the local capacity for firefighting was severely limited. The ranks of the local fire brigade reflected the state of the local population, with too few volunteers, many of whom were aged over 65 . Consequently, there was a heavy reliance on non-local firefighters who had been deployed to an area with which they were largely unfamiliar. This problem was compounded by the fact that most local firefighters stayed with their own properties to defend their homes and assets.

\subsection{Coping and adaptive capacities}

The bushfires had a range of impacts on the health, finances and livelihoods, and social lives of local people. This section discusses people's capacities and strategies for coping and adapting to these impacts.

\section{Health}

Although no one was killed or seriously injured, health services reported an increase in mental health issues after the fires, including incidences of post-traumatic stress, depression and anxiety. These were prevalent among those who lost their home and/or large quantities of 
livelihood assets. For many, the most traumatic experiences involved witnessing the suffering of animals and destroying injured livestock:

Losing the house was pretty hard, because there was a lot of family stuff in there - antiques, books, photos... But probably the animals... I felt bad about them because I was responsible for them... And I let them down.

'Kelvin', Seldom Seen

In some cases mental health impacts were immediately apparent, with some residents recognising symptoms of shock. However, many health impacts took longer to emerge. One local health worker observed that a lot of people 'fell over' 12 to 18 months after the fires, when most of the recovery programs had ended. A grazier who suffered huge losses of stock and other assets explained that he coped 'pretty good for a start, but I had a rough stage after nine to twelve months; after I started to despair quite a bit' (Alan, Wulgulmerang). Health workers also noted that some people worked so hard after the fires they failed to recognise symptoms of ill-health that later became more serious.

Previous life stress, trauma and family histories of mental illness have all been found to influence the incidence of post-traumatic stress from bushfires (Byrne et al., 2006). Studies have also drawn attention to increased rates of stress, anxiety, depression, grief, anger and family breakdown resulting from drought in many parts of rural Australia (Alston, 2007). The cumulative effects of drought, Ovine Johne's Disease and financial pressures on the health of local people, particularly graziers, cannot be underestimated. The connections between these earlier stresses and the bushfires were captured by two local health workers: 
Farmers have such a hard life. There's one guy up there who's been in years and years of drought, then he got Ovine Johne's Disease and he had to get rid of all his breeding stock, and then the fire came through and burnt him out. But he just keeps going on. They're incredibly tough. I'm still surprised no one committed suicide...

Bush Nurse, Gelantipy

They would normally be really resilient people - they'd bounce back and they'd bounce back. And they're really good at doing that. But you can't get knocked down consistently and keep bouncing back.

Counsellor, Lakes Entrance

Despite concern that suicide rates may be rising in rural Australia - particularly due to pressures associated with drought (Hussey, 2007) - research challenges the perception that rural people suffer higher rates of mental illness than those in metropolitan areas (Morrissey and Reser, 2007). Judd et al. (2006) suggest that higher rates of suicide among farmers reflect factors that limit their ability to acknowledge or seek help for problems, rather than higher rates of mental illness per se. People in rural and remote areas tend to have much poorer access to healthcare services, while masculine cultures of self-reliance and independence mean that men are less likely to seek help (Alston and Kent, 2008; Alston, 2011b).

The Gelantipy Bush Nurse was the main provider of basic healthcare, with counselling and other services provided through home-visits from Bairnsdale (approx. $140 \mathrm{~km}$ away). The district's remoteness meant that these services were provided on a relatively limited basis, and 
only for a period of around 18 months. Health workers experienced particular difficulty reaching men, many of who considered themselves too busy, or denied they needed help.

People were depressed - that was another hard thing after the fires, especially for the men. The women would come and talk to me and they'd say 'My husband's not sleeping' and just [describe] all the classical signs of depression. But they wouldn't see the doctor for depression in a fit. Some of them finally did, which was good, but some of them didn't...

\section{Counsellor, Lakes Entrance}

A local nurse described farming men as 'a pretty hard group to engage', noting that it was more effective to deal with them in social rather than medical settings. Health workers emphasised the advantages of adopting an informal approach to their work, with some men willing to discuss their experiences over a beer or at the local football match. They also emphasised the need to provide post-disaster health services beyond the immediate crisis and short-term recovery, to ensure that people with ongoing issues have access to appropriate care.

\section{Finances and livelihoods}

The most immediate impacts of the bushfires were losses of homes and livelihood assets. An assessment of agricultural losses in north-eastern Victoria and East Gippsland (Whittaker, 2008) showed that losses of homes, farm buildings, livestock, fences and fodder were proportionally greater in the Wulgulmerang district than in any other part of Victoria affected by the 2003 fires. This is partly attributable to the district's traditional agricultural economy and its greater share of large, asset-laden commercial farms. Just $10 \%$ of properties assessed 
in Wulgulmerang were 'hobby farms', compared to $24 \%$ in the Omeo region, $42 \%$ in Stanley and $59 \%$ in Eldorado; the latter being examples of more diversified rural economies.

Local people employed a range of strategies to cope and adapt to these impacts. For most people, insurance was the primary strategy for recovering losses. Two broad types of insurance are available: home insurance, which covers landholders against certain types of damage or loss of the home buildings and/or its contents; and business insurance, which covers damage to or loss of assets, as well as claims of liability or workers' compensation. Many insurance companies offer policies that are tailored to the needs of rural landholders, such as the Wesfarmers Federation Insurance (2011) 'Rural Plan', which specifically covers day-to-day risks faced by farm businesses. Critically, the research revealed that although residents and landholders typically had insurance for their homes and contents, many were uninsured or significantly underinsured for damage to livelihood assets such as farm fences, livestock and sheds. In much of the hazards literature, non-insurance and underinsurance are attributed to the faulty risk perceptions and flawed decisions of those at risk (e.g. Mileti, 1999: 168-9).

A more holistic perspective on the problem of non-insurance and underinsurance would also consider the cultural, economic, political and social factors that prevent people from attaining an adequate level of cover. Priest et al. (2005) argue that the underinsured are often the most economically and socially vulnerable members of society. They note that many people are excluded from insurance markets for financial reasons, including those on low incomes and those who reside in high-risk, high-premium areas. Certainly some people in the Wulgulmerang district had undervalued or forgotten to reinsure assets. Yet many were knowingly underinsured because they could not afford comprehensive insurance. Some 
farmers explained that their underinsurance was a direct result of drought and other financial pressures on their businesses. Investments to maintain livelihoods, such as the purchase of hay to feed livestock through the drought, were a more pressing concern than maintaining a high level of insurance cover.

We didn't have fences insured, because when you're going through drought you've got to get your priorities right - you've got to keep your money to keep your stock alive. You've got to either agist them out or, if you can't find agistment, you [buy] feed. So you need all your resources to feed your stock to get them through.

Joe, Wulgulmerang

With the benefit of hindsight, one could say that these people inaccurately assessed their exposure to bushfire hazard. However, at the time, drought was a far more real and immediate threat to people's livelihoods than bushfires or indeed any other agent of property loss. Some farmers explained that it was not economically viable to reduce their herds during the drought, because oversupply meant prices were low. Many were also reluctant to sell valuable breeding stock and face the prospect of rebuilding their herds. Understandably, then, many farmers channelled their limited resources toward the problem at hand - drought - rather than an uncertain, future event. Drought and other livelihood pressures are pivotal to understanding people's vulnerability to bushfires.

Previously discussed changes to the nature of farming have also contributed to the underinsurance problem. It has been noted that many farmers have progressively restructured their businesses, resulting in larger landholdings with greatly increased capital bases. 
However, farm incomes have not risen accordingly and many farmers now find themselves with an increased asset base - including more kilometres of fences, additional livestock, farm buildings and pasture - but not the resources to insure it.

Yes, we were insured. And I might add that the insurance company was incredibly good after the fires and paid everything up. But since then the premiums have gone up quite a lot and we've had to change our insurance around a bit, insuring some things for more and some things for less.

Alan, Wulgulmerang

The ultimate consequence of underinsurance has been that many people have taken out loans to repair and replace damaged livelihood assets, or have simply accepted losses and scaled down their business, placing even greater financial pressure on households. Insurance premiums have also risen. This is akin to the 'ratchet effect' of vulnerability, 'where each succeeding event reduces the resources a group or individual has to resist and recover from the next environmental shock or stress' (Pelling, 2003: 16; Chambers, 1989). The 'ratchet effect' of underinsurance means that, once impacted, people have fewer resources to insure assets into the future and that a greater share of income may be diverted away from households, further adding to economic disadvantage (see Rural and Regional Committee, 2010).

Accessing government assistance was another important strategy for coping and adapting, particularly considering the extent of underinsurance. Those who lost their homes were entitled to apply for a series of grants totalling AUD 22,800 to help cover the costs of initial expenses, temporary accommodation and the repair and refurnishing of their homes. Other 
forms of financial assistance, such as low interest loans to repair and replace damaged assets, were also available. However, the formal procedures for accessing this assistance discouraged some people, at least initially, from applying. It is significant that frustration with application procedures was most often expressed by older, farming men. Women often took responsibility for seeking and accessing assistance. Their greater capacities for performing these tasks can be attributed to the fact that many were or had previously been employed in professions that require these skills, such as nursing and teaching, and because women are often responsible for the day-to-day administration of farm businesses (Alston, 2011a).

In 2001, more of the district's women (55\%) had completed Year 12 of their schooling than men (17\%). Also, while more than two-thirds of women (69\%) described themselves as 'professionals' or 'clerical workers' there were no men in these categories (ABS, 2001). The generally lower capacity of men to access resources through official channels suggests that male-only households may be less able to cope with bushfire impacts. This is supported by the experiences of two elderly men, both of whom lived alone and lost their homes, who were deterred by the formal procedures for accessing assistance and only did so after friends insisted on helping.

Participation in social networks was another important means for accessing resources to cope and adapt. Donations of domestic goods, such as food and clothing, as well as agricultural supplies and volunteer labour came from outside the district, including from family and friends, farmers and industry groups, churches, rural fire brigades, sports and other clubs. Farmers had extensive social networks based on trade associations, as well as their shared sense of identity and solidarity with farming people. Popular support for farmers meant that some received goods and labour from non-farmers with whom they had no prior association. 
We received help from Lions, Rotary, fire brigades... One bloke, he took two months of work and just went to everyone's place for a week. All we had to do was put him up and he worked... People sent anonymous cheques - you couldn't trace them... We were donated a lot of agistment. I dare say we wouldn't be here if we hadn't received that help.

Alan, Wulgulmerang

Households also had to cope and adapt to numerous longer-term impacts. By destroying livelihood assets, the fires reduced the productivity of many businesses. Regardless of their insurance cover, affected farmers reported reduced incomes in the months and years after the fires. The lack of pasture and farm fences forced many graziers to reduce their livestock numbers until grass regrew and fences were repaired or replaced. Furthermore, drought meant that farmers faced high prices for hay to feed remaining livestock. While costly, this was preferable to losing years of breeding and having to rebuild herds from scratch. Higher cattle prices after the fires alleviated the impacts of some of these costs; however, other strategies were required to cope with the reduced productivity of farm businesses.

Seeking off-farm income is a common strategy among Australian farmers for coping with drought and other financial pressures (Gray and Lawrence, 2001; Black, 2005). In the Wulgulmerang district, two thirds of interviewed farming households had at least one person engaged in off-farm employment on a casual or part-time basis. These included occasional jobs on neighbouring farms (particularly absentee landholdings), as well as other local businesses and community services. However, limited opportunities for local employment meant that some people sought work elsewhere. By compensating for lost income, off-farm 
employment helped households to meet basic needs and cover some of the additional costs imposed by the fires. The fact that farmers had endured drought and declining terms of trade prior to the January 30 bushfires meant that many were already engaged in off-farm employment and were thus better placed to cope and adapt to the fires' impacts.

From a sustainable livelihoods perspective, Oughton and Wheelock (2003) argue that the partial containment of 'micro-businesses' within households means that it is impossible to understand the two separately. In the UK, for example, rural households were found to absorb the costs of the Foot and Mouth Disease epidemic through adjustments in the wages taken from businesses, restrictions of household spending, and the use of personal savings (Phillipson et al., 2004). Australian farm households adopt similar strategies to cope with drought and other financial pressures (Gray and Lawrence, 2001). Responses to the January 30 bushfires also highlight the inseparability of farm businesses and households. Many households absorbed the costs to farm businesses by reducing income, using personal savings, and restricting expenditure on household goods and non-essentials.

\section{Social and community life}

Immediately after the fires, a sense of shared experience and solidarity provided the foundation for a newfound social cohesion among residents and landholders. Longstanding divisions were broken down as people shared donated goods, and worked cooperatively to clean up the district. This is consistent with sociological disaster research, which suggests that individuals and groups often become more cohesive as they strive to overcome disasterinduced challenges (Fritz, 1961; Drabek and McEntire, 2003; Tierney, 2006). 
To some extent this was the case in the Wulgulmerang district. Increased social cohesion after the fires enabled a more cooperative, inclusive and efficient approach to the allocation and distribution of resources. However, this cohesion was neither all-encompassing nor lasting. A small number of local people felt that the communal response was socially exclusive and divisive, particularly the sharing of donated goods and other support. These included nonfarmers, 'alternative lifestylers' and others who were considered (or considered themselves) 'outsiders' in the community. Moreover, after an initial period of increased cohesion, and as people began to recover, the pre-existing divisions were gradually re-established. The fact that the northern part of the district had been more severely affected than the southern part exacerbated these divisions to the point where one resident questioned whether there were, in reality, two separate districts. Some believed that Gelantipy had received greater support during and after the fires, despite being less affected.

My personal opinion is that afterwards - and I don't know whether it was through guilt or what, because they weren't affected like us - some people from Gelantipy tried to make out that we were crying over spilt milk, particularly as all the fire trucks were down there when it came through. I personally think it's highlighted that there's a district up here and a district down there.

Jenny, Wulgulmerang.

Unmet expectations of firefighting support, in particular, created tensions that prompted a small number of volunteers to resign from the Gelantipy fire brigade. While those who criticised the CFA stressed that their complaint was with the bureaucracy and not the local brigade, the CFA Captain at Gelantipy, himself a volunteer, maintained that grievances and 
tension had filtered through to the local level. He downplayed the impact of the few resignations on the brigade:

Well we haven't got any [volunteers] anyway! Ah, look, I think it just needs another fire to come through and they'll realise they need a brigade and it'll be alright again. But yeah, there's definitely a couple of them who don't want to belong to it.

\section{Captain, Gelantipy CFA}

It is important to emphasise that despite pre-existing social divisions and the strain the fires placed on some relationships, people were, on the whole, able to work together and help each other when it mattered most. Furthermore, a number of residents later re-joined the local fire brigade and continue to participate in community life.

\section{Discussion and conclusion}

The bushfires that swept through the Wulgulmerang district in 2003 occurred at a particular moment of vulnerability. Changes to the nature of local livelihoods had profoundly transformed the social and economic foundations of the district. In particular, the deregulation of agriculture had led to declining farm incomes, property amalgamations and enlargements, cost-cutting and the out-migration of agricultural workers and their families. As a result, the district experienced depopulation, a contraction of local economic activity, business closure, service withdrawal, and a breakdown of local institutions and networks. The pressure on individual households and the district as a whole was amplified by a prolonged and severe drought. As this paper has shown, many of these pressures and challenges increased people's 
exposure to bushfire hazards and January 30, 2003, and diminished their capacities to cope and adapt to impacts.

The case study highlights the importance of understanding the human dimensions of hazard exposure. As Burton et al. $(1993,32)$ note, environmental processes and become hazards when they interact with the 'human use system' of locations, livelihoods and social organisation. This is evident in differences in the hazard exposure of agricultural and nonagricultural landholders. Residential and holiday homes were often located in the highest bushfire risk areas, typically for their high-amenity values. However, because they were insured and their livelihoods were not at stake, most of these residents left or stayed away from their properties during the fires. Farming families, in contrast, had a greater share of their total asset base at risk and therefore faced the prospect of far greater economic losses. Moreover, their exposure had increased as a result of the shift to larger, more asset-laden farms, as well as the diminished capacity for farm and district scale firefighting. Not surprisingly, they often accepted the risks of staying to defend their assets and livelihoods.

Environmental conditions were clearly an important factor in people's exposure during the bushfires. Just as physical scientists have been criticised for neglecting the human dimensions of hazards and disasters, it has been argued that social scientists have often neglected environmental factors in their analyses (Blong, 1997; Brookfield, 1999; Cardona, 2004). As noted, a prolonged period of severe rainfall deficiency and higher than average temperatures had increased the amount of fuel, while high temperatures, strong winds, and low humidity combined to produce extreme fire behaviour on the day. The extent of the fires, which were burning throughout north-eastern Victoria and East Gippsland, meant that firefighting capacity was extremely limited. Although most residents and landholders were not prepared 
for the scale and severity of the fires, the long build-up meant that most people had time to implement basic preparedness measures.

The many pressures and challenges of everyday life in the district also influenced residents' and landholders' capacities to cope and adapt. Insurance is a primary mechanism for recovering losses incurred due to hazards and is therefore and important determinant of coping and adaptive capacities (Pelling, 2003). A key finding of the research is that while most residents had home and contents insurance, many farmers were uninsured or underinsured for damage to their livelihood assets. While non-insurance and underinsurance are often attributed to the faulty perceptions and flawed decisions of those at risk, economic factors are at least equally important (Priest et al., 2005). The cost of premiums was the main barrier to insurance, with longstanding drought and other financial pressures on farm households resulting in reduced expenditure on business risk management. The aforementioned changes to the nature of farming and local livelihoods also contributed to the underinsurance problem. Increases in farm sizes and asset bases did not correspond with increased revenue, meaning that many farmers did not have the resources to fully insure their livelihood assets.

Most people were well-integrated into social networks of support and were able to access government assistance, which provided them with resources to begin to cope and adapt. However, many farm businesses experienced reduced productivity as a result of the fires. Offfarm employment was an important strategy for compensating lost income, as it is throughout rural Australia (Gray and Lawrence, 2001; Black, 2005). Off-farm income allowed households to meet basic needs and cover some of the costs incurred as a result of the fires. However, many households absorbed the longer-term costs to farm businesses by reducing 
income and expenditure on household goods and non-essentials. While such coping strategies may help to keep small businesses and rural economies afloat, they may increase the social and economic disadvantage of rural households (Phillipson et al. 2004; Rural and Regional Committee, 2010), further adding to vulnerability.

Limited access to post-disaster health services was a major factor hindering coping and recovery from the fires. While it is fortunate that no one died or was seriously injured, the impact on people's psychological health was profound. Capacities for coping were undermined by the limited provision of local health services and a general reluctance, particularly among men, to seek help. Women played a vital role in persuading and helping their partners and other local men to access help services. However, these services ended 18 months after the fires, when many people were only beginning to access them. Given the district's small population and recent history of service withdrawal, it is unlikely that calls for longer-term provision of local, post-disaster services will be realised.

This paper demonstrates how vulnerability can arise from the circumstances of people's everyday lives. In illuminating the underlying causes of vulnerability in the Wulgulmerang district, it contributes to the growing body of research that seeks to better understand the human dimensions of hazards and disasters. Importantly, the paper also raises the question of what can be done to reduce vulnerability in the district. Climate change projections suggest that East Gippsland will be hotter and drier in the future, with an increased risk of damaging bushfires (Hennessy et al., 2005; Lucas et al., 2007). An increase in the severity of droughts is likely to amplify the pressures on farm households and may increase the risks associated with underinsurance. In addition, there is an increased risk of successive droughts and bushfires in relatively short periods of time, which, together, may exceed people's capacities to cope and 
adapt. To reduce vulnerability to bushfires, as well as drought and other shocks and stresses, a holistic development agenda must be pursued. Strategic planning and policy should aim to build the social and economic viability of the district by revitalising and diversifying the local economy, attracting new businesses and residents, and increasing access to basic services. Projections of a warmer climate and fewer frosts suggest opportunities for the development of new industries, including horticulture and viticulture (DSE, 2004). However, the district's remoteness and lack of essential services, particularly schooling, represent a significant challenge to revitalisation. More immediately, fire and emergency services must develop policies and programs to provide remote, rural communities with greater protection and support before, during and after bushfires, recognising that these communities may have limited capacities to protect themselves. 


\section{References:}

Adger, N., 2006. Vulnerability. Global Environmental Change 16, 268-81.

Adger, W.N., Brooks, N., Bentham, G., Agnew, M., Erisksen, S., 2004. New indicators of vulnerability and adaptive capacity. Technical Report 7. Tyndall Centre for Climate Change Research, Norwich, U.K.

Alston, M., 2007. Globalisation, rural restructuring and health service delivery in Australia: policy failure and the role of social work? Health and Social Care in the Community 15 (3), 195-202.

Alston, M., 2011a. Gender and climate change in Australia. Journal of Sociology 47, 53-70.

Alston, M., 2011b. Rural male suicide in Australia. Social Science and Medicine.

Doi:10.1016/j.socscimed.2010.04.36

Alston, M., Kent, J., 2008. The big dry: the link between rural masculinities and poor health outcomes for farming men. Journal of Sociology 44 (2), 133-47.

Argent, N., Tonts, M., Jones, R., Holmes, J., 2010. Amenity-led migration in rural Australia: a new driver of local demographic and environmental change? In: Luck, G.W, Black, R., Race, D. (Eds), Australia's rural landscapes: implications for society and the environment. Springer, Munich. 
Australian Bureau of Statistics (ABS), 2001. Census of population and housing. Available at: http://www.abs.gov.au

Australian Bureau of Statistics, 2005. Australia's beef cattle industry. In: Trewin, D. (Ed.), Yearbook Australia. ABS catalogue no. 1301.0. Commonwealth of Australia, Canberra.

Australasian Fire Authorities Council (AFAC), 2005. Position paper on bushfires and community safety. AFAC Limited, Melbourne.

Ball, N., 1975. The myth of the natural disaster. The Ecologist 5, 368-69.

Bazeley, P. 2007. Qualitative data analysis with NVivo. Sage Publications, Thousand Oaks.

Berkes, F., Folke, C. 1998. Linking social and ecological systems: management practices and social mechanisms for building resilience. Cambridge University Press, Cambridge.

Black, A., 2005. Rural communities and sustainability. In: Cocklin, C., Dibden, J. (Eds.), Sustainability and change in rural Australia. UNSW Press, Sydney.

Blong, R., 1997. A geography of natural perils. Australian Geographer 28, 7-27.

Bohle, H.G., Downing, T.E., Watts, M.J., 1994. Climate change and social vulnerability: toward a sociology and geography of food insecurity. Global Environmental Change 4, 37-48. 
Bradstock, R.A., Gill, A.M., 2001. Living with fire and biodiversity at the urban edge: in search of a sustainable solution to the human protection problem in southern Australia. Journal of Mediterranean Ecology 2: 179-95.

Bradstock, R.A., Hammill, K.A., Collins, L., Price, O., 2010. Effects of weather, fuel and terrain on fire severity in topographically diverse landscapes of south-eastern Australia. Landscape Ecology 25, 607-19.

Brookfield, H., 1999. Environmental damage: distinguishing human from geophysical causes. Environmental Hazards 1, 3-11.

Bureau of Meteorology, 2003a. Submission to the Victorian Emergency Services Commissioner's inquiry into the 2002/3 bushfires. Commonwealth of Australia, Melbourne.

Bureau of Meteorology, 2003b. Meteorological aspects of the eastern Victorian fires, January - March 2003. Commonwealth of Australia, Melbourne.

Bureau of Meteorology, 2007. El Niño - detailed Australian analysis. http://www.bom.gov.au/climate/enso/australia_detail.shtml

Burnley, I., Murphy, P., 2004. Sea change: movement from metropolitan to Arcadian Australia. UNSW Press, Sydney.

Burton, I., Kates, R.W., White, G.F., 1978. The environment as hazard. Oxford University Press, New York. 
Burton, I., Kates, R.W., White, G.F., 1993. The environment as hazard. Second edition. The Guilford Press, New York.

Byrne, M., Lerias, D., Sullivan, N., 2006. Predicting vicarious traumatization in those indirectly exposed to bushfires. Stress and Health 22, 167-77.

Cannon, T., 2000. Vulnerability analysis and disasters. In: Parker, D.J. (Ed.), Floods. Routledge, London.

Cardona, O.D., 2004. The need for rethinking the concepts of vulnerability and risk from a holistic perspective: a necessary review and criticism for effective risk management. In: Bankoff, G., Frerks, G., Hilhorst, D. (Eds), Mapping vulnerability: disasters, development and people. Earthscan, London.

Chambers, R., 1989. Editorial introduction: vulnerability, coping and policy. IDS Bulletin 20, $1-7$.

Cocklin, C., Dibden, J. (Eds.), 2005. Sustainability and change in rural Australia. UNSW Press, Sydney.

Costello, L., 2007. Going bush: the implications of urban-rural migration. Geographical Research 45, 85-94. 
Cottrell, A., 2005. Communities and bushfire hazard in Australia: more questions than answers. Global Environmental Change Part B: Environmental Hazards 6, 109-14.

Country Fire Authority (CFA), Department of Sustainability and Environment (DSE), 2003. Gelantipy / Wulgulmerang, 30 January 2003: summary of Near Miss Investigation for Chief Officers of CFA and DSE and their response. State Government of Victoria, Melbourne.

Cutter, S.L., 1996. Vulnerability to environmental hazards. Progress in Human Geography 20, 529-39.

Department of Sustainability and Environment (DSE), 2004. Climate change in East Gippsland. Available at: http://www.climatechange.vic.gov.au/CA256F310024B628/0/CF7EA29FFB2C9881CA2571 9B000557CA/\$File/East+Gippsland.pdf

Dow, K., 1992. Exploring differences in our common future(s): the meaning of vulnerability to global environmental change. Geoforum 23, 417-36.

Drabek, T.E., McEntire, D.A., 2003. Emergent phenomena and the sociology of disaster: lessons, trends and opportunities from the research literature. Disaster Prevention and Management 12, 97-112.

East Gippsland Shire Council (EGSC), 2007. East Gippsland Planning Scheme. Available at: http://www.dse.vic.gov.au/planningschemes/aaCombinedPDFs/EastGippsland_PS_Ordinance . pdf 
Eriksen, C., Gill, N., Head, L., 2010. The gendered dimensions of bushfire in changing rural landscapes in Australia. Journal of Rural Studies 26, 332-42.

Eriksen, C., Gill, N., 2010. Bushfire and everyday life: examining the awareness-action 'gap' in changing rural landscapes. Geoforum 41, 814-25.

Fernandes, P.M., Botelho, H.S. A review of prescribed burning effectiveness in fire hazard reduction. International Journal of Wildland Fire 12, 117-28.

Folke, C. 2006. Resilience: the emergence of a perspective for social-ecological systems analyses. Global Environmental Change 16, 253-67.

Fordham, M., 2004. Gendering vulnerability analysis: towards a more nuanced approach. In: Bankoff, G., Frerks, G., Hilhorst, D. (Eds.) Mapping vulnerability: disasters, development and people. Earsthscan Publications, London.

Fritz, C., 1961. Disasters. In: Merton, R., Nisbet, R. (Eds.) Contemporary social problems. Harcourt, New York.

Gill, N., 1994. The cultural politics of resource management: the case of bushfires in a conservation reserve. Australian Geographical Studies 32, 224-40.

Gleeson, T., McDonald, D., Hooper, S., Martin, P., 2003. Australian beef industry 2003: report on the Australian Agricultural and Grazing Industries Surveys of Beef Producers. 
ABARE research report 03.3. Australian Bureau of Agricultural and Resource Economics, Canberra.

Gould, J., 2006. Fuel management - an integral part of fire management: trans-Tasman perspective. In: Andrews, P.L., Butler, B.W. (Eds.), Fuels management - how to measure success: conference proceedings. Forest Service, USDA, Fort Collins.

Gray, I., Lawrence, G., 2001. A future for regional Australia: escaping global misfortune. Cambridge University Press, Oakleigh.

Handmer, J., 2003. We are all vulnerable. The Australian Journal of Emergency Management $18,55-60$.

Handmer, J., Haynes, K., 2008. Community bushfire safety. CSIRO Publishing, Collingwood.

Handmer, J., O’Neill, S., Killalea, D. 2010. Review of fatalities in the February 7, 2009, bushfires. Available at: http://www.bushfirecrc.com/research/downloads/Review-of-fatalitiesin-the-February-7.pdf

Handmer, J., Tibbits, A., 2005. Is staying at home the safest option during bushfires?

Historical evidence for an Australian approach. Global Environmental Change Part B: Environmental Hazards 6, 81-91. 
Haynes, K., Handmer, J., McAneney, J., Tibbits, A., Coates, L., 2010. Australian bushfire fatalities 1900-2008: exploring trends in relation to the 'Prepare, stay and defend or leave early’ policy. Environmental Science and Policy 13, 185-94.

Henessy, K., Lucas, C., Nichols, N., Bathols, J., Suppiah, R., Ricketts, J., 2005. Climate change impacts on fire-weather in south-east Australia. CSIRO, Aspendale.

Hewitt, K., 1980. Review of 'The environment as hazard'. Annals of the Association of American Geographers 70, 306-11.

Hewitt, K., 1983. The idea of calamity in a technocratic age. In: Hewitt, K. (Ed.)

Interpretations of calamity from the viewpoint of human ecology. Allen \& Unwin, London.

Hewitt, K., 1997. Regions of risk: a geographical introduction to disasters. Longman, Harlow.

Hewitt, K., 1998. Excluded perspectives in the social construction of disaster. In: Quarantelli, E.L. (Ed.), What is a disaster? Perspectives on the question. Routledge, London.

Hodgson, S., Papadakis M., 2003. Gippsland fire toll is 39 houses. Sunday Herald Sun, February $2^{\text {nd }}, 8$.

Hughes, R., Mercer, D., 2008. Planning to reduce risk: the Wildfire Management Overlay in Victoria, Australia. Geographical Research 41, 124-41. 
Hugo, G., 2005. The state of rural populations. In: Cocklin, C., Dibden, J. (Eds.)

Sustainability and change in rural Australia. UNSW Press, Sydney.

Hussey, G., 2007. Outback depression situation near crisis point, health conference told. Available at: http://www.abc.net.au/7.30/content/2007/s1925070.htm

Jasper, R.G., 1999. The changing direction of land managers in reducing the threat from major bushfires on the urban interface of Sydney. In: Lunt, I., Green, D.G. (Eds.), Proceedings of the Australian Bushfire Conference. Charles Sturt University, Albury.

Judd, F., Jackson, H., Fraser, C., Murray, G., Robins, G., Komiti, A., 2006. Understanding suicide in Australian farmers. Social Psychiatry and Psychiatric Epidemiology 41, 1-10.

Kasperson, R.E., Dow, K., 1993. Hazard perception and geography. In: Garling, T., Golledge, R.G. (Eds.), Behavior and environment: psychological and geographical approaches. Elsevier Science Publishers B.V., New York.

Kelly, P.M., Adger, W.N., 2000. Theory and practice in assessing vulnerability to climate change and facilitating adaptation. Climatic Change 47, 325-52.

Kiem, A.S., Vernon-Kidd, D.C., 2010. Towards understanding hyroclimatic change in Victoria, Australia - preliminary insights into the 'Big Dry'. Hydrology and Earth System Sciences $14,433-45$. 
Lawrence, G., 1987. Capitalism and the countryside: the rural crisis in Australia. Pluto Press, Leichhardt.

Lucas, C., Hennessy, K., Mills, G., Bathols, J. 2007. Bushfire weather in southeast Australia: recent trends and projected climate change impacts. CSIRO, Melbourne.

Martin, W.E., Martin, I.M., Kent, B. The role of risk perceptions in the risk mitigation process: the case of wildfire in high risk communities. Journal of Environmental Management 91, 489-98.

McCaffrey, S. 2004. Thinking of wildfire as a natural hazard. Society and Natural Resources $17,509-16$.

Mileti, D., 1999. Disasters by design: a reassessment of natural hazards in the United States. Joseph Henry Press, Washington, D.C.

Miller, C., 2003. After the inferno, hope, acts of kindness and red tape. The Age, February $22^{\text {nd }}, 4$.

Morrissey, S.A., Reser, J.P., 2007. Natural disasters, climate change and mental health considerations for rural Australia. Australian Journal of Rural Health 15, 120-25.

Murray, R., White, K., 1995. State of fire: a history of volunteer firefighting and the Country Fire Authority in Victoria. Hargreen Publishing Company, North Melbourne. 
Mustafa, D., 1998. Structural causes of vulnerability to flood hazard in Pakistan. Economic Geography 74, 289-305.

Niemi, E., Lee, K., 2001. Wildfire and poverty: an overview of the interactions among wildfires, fire-related programs, and poverty in the western States. The Centre for Watershed and Community Health, Portland, OR.

O'Keefe, P., Westgate, K., Wisner, B., 1976. Taking the naturalness out of natural disasters. Nature 260, 566-67.

Oughton, E., Wheelock, J., 2003. A capabilities approach to sustainable household livelihoods. Review of Social Economy 61, 1-22.

Peet, R., Thrift, N., 1989. Political economy and human geography. In: Peet, R., Thrift, N. (Eds.), New models in geography: the political economy perspective. Volume 2. Unwin Hyman, London.

Pelling, M., 2003. The vulnerability of cities: natural disasters and social resilience. Earthscan Publications, London.

Phillipson, J., Bennett, K., Lowe, P., Raley, M., 2004. Adaptive responses and asset strategies: the experience of rural micro-firms and Foot and Mouth Disease. Journal of Rural Studies 20, 227-43. 
Priest, S.J., Clark, M.J., Treby, E.J., 2005. Flood insurance: the challenge of the uninsured. Area 37, 295-302.

Productivity Commission, 2005. Trends in Australian agriculture. Commonwealth of Australia, Melbourne.

Rural and Regional Committee, 2010. Inquiry into the extent and nature of disadvantage and inequity in rural and regional Victoria. Parliament of Victoria, Melbourne.

Schauble, J., 2004. The Australian bushfire safety guide. Harper Collins, Sydney.

Taylor, J., Webb, R., 2005. Meteorological aspects of the January 2003 south-eastern Australia bushfire outbreak. Australian Forestry 68, 94-103.

Teague, B., McLeod, R., Pascoe, S., 2010. 2009 Victorian Bushfires Royal Commission final report: summary. Available at:

http://www.royalcommission.vic.gov.au/finaldocuments/summary/HR/VBRC_Summary_HR. pdf

Thomas, D.R., 2006. A general inductive approach for analyzing qualitative evaluation data. American Journal of Evaluation 27, 237-46.

Tierney, K., 2006. Social inequality, hazards, and disasters. In: Daniels, R.J., Kettl, D.F., Kunreuther, H. (Eds.) On risk and disaster: lessons from Hurricane Katrina. University of Pennsylvania Press, Philadelphia. 
Timmerman, P., 1981. Vulnerability, resilience and the collapse of society. Environmental Monograph 1. Institute for Environmental Studies, University of Toronto, Toronto.

Tonts, M., 2000. The restructuring of Australia's rural communities. In: Pritchard, B., McManus, P. (Eds.), Land of discontent: the dynamics of change in rural and regional Australia. UNSW Press, Sydney.

Tonts, M., Haslam-McKenzie, F., 2005. Neoliberalism and changing regional policy in Australia. International Planning Studies 10, 183-200.

Torry, W.I., 1979. Hazards, hazes and holes: a critique of 'The environment as hazard' and general reflections on disaster research. Canadian Geographer 23, 368-83.

Waddell, E., 1977. The hazards of scientism. Human Ecology 5, 69-76.

Wakefield, N.A., 1970. Bushfire frequency and vegetational change in south-eastern Australian forests. Victorian Naturalist 87, 152-58.

Walker, B., Westley, F. 2011. Perspectives on resilience to disasters across sectors and cultures. Ecology and Society 16, 4.

Walker, R.A., 1979. Review of 'The environment as hazard'. Geographical review 69, 11314. 
Wareing, K., Flinn, D., 2003. The Victorian Alpine Fires: January - March 2003. Department of Sustainability and Environment, State Government of Victoria, East Melbourne.

Watts, M.J., 1983. On the poverty of theory: natural hazards research in context. In: Hewitt, K. (Ed.), Interpretations of calamity from the viewpoint of human ecology. Allen \& Unwin, London.

Watts, M.J., Bohle, H.G., 1993. The space of vulnerability: the causal structure of hunger and famine. Progress in Human Geography 17, 43-67.

Webster, J., 1986. The complete Australian bushfire book. Penguin Books, Melbourne.

Wesfarmers Federation Insurance, 2011. Rural plan: product disclosure statement. Available at: http://www.wfi.com.au/wps/wcm/connect/internet/wfi/resources/c875f700487953dcb999b96a db95ec72/100419_RuralPlan_SPDS.pdf

Whittaker, J., 2008. Vulnerability to bushfires in south-eastern Australia: a case study from East Gippsland, Victoria. Unpublished PhD thesis. RMIT University, Melbourne. Available at: http://adt.lib.rmit.edu.au/adt/public/adt-VIT20090401.122025/

Whittaker, J., Haynes, K., Handmer, J., McLennan, J., forthcoming. Community safety during the 2009 'Black Saturday' bushfire disaster: an analysis of household preparedness and response. International Journal of Wildland Fire. 
Whittaker, J., Mercer, D. 2004. The Victorian bushfires of 2002-03 and the politics of blame: a discourse analysis. Australian Geographer 3, 259-87.

Winter, G., Fried, J.S. 2000. Homeowner perspectives on fire hazard, responsibility, and management strategies at the wildland-urban interface. Society and Natural Resources 13, 3349.

Wisner, B., Blaikie, P., Cannon, T., Davis, I., 2004. At risk: natural hazards, people's vulnerability and disasters. Second edition. Routledge, London.

Wood, G., Berry, M., Taylor, E., Nygaard, C., 2008. Community mix, affordable housing and metropolitan planning strategy in Melbourne. Built Environment 34, 273-90.

Yates, J., 2008. Australia's housing affordability crisis. The Australian Economic Review 41, $200-14$

Zimmerer, K.S., Basset, T.J., 2003. Approaching political ecology: society, nature, and scale in human-environment studies. In: Zimmerer, K.S., Basset, T.J. (Eds.), Political ecology: an integrative approach to geography and environment-development studies. The Guilford Press, New York.

\footnotetext{
${ }^{1}$ All climate data are sourced from the Automatic Weather Station at Gelantipy (AWS no. 084142).

${ }^{2}$ All names are pseudonyms.

${ }^{3}$ Gough Whitlam was the Prime Minister of Australia from 1972 to 1975.

${ }^{4}$ Collins Street is the premier street in Melbourne's CBD. The term 'Collins Street Farmer' was used to refer to those who invest in farm properties, often for tax purposes, but live and work in Melbourne.

${ }^{5}$ The term 'community' is used throughout this paper to refer to the people of the Wulgulmerang district in a collective sense. It is recognised that communities 'are characterized as much by their heterogeneity as by their (uneasy) alliance around certain issues' (Zimmerer and Basset, 2003: 6) and may not be socially inclusive or cohesive. In the Wulgulmerang district, people's shared isolation and the inaccessibility of basic goods and services, particularly education, means they face common issues and challenges that require local action. People
} 
generally identify as belonging to 'the' local community, but acknowledge that people don't always agree or get along.

${ }^{6}$ The assertion that 'ordinary' people can safely defend their homes from bushfires was drawn into question after the 2009 'Black Saturday' bushfires in Victoria. 173 people died, including 113 inside houses, and more than 2000 houses were destroyed. Despite calls for the 'Prepare, stay and defend or leave early' policy to be shelved, research found that most of those who died had not been actively defending and were not adequately prepared (Handmer et al. 2010). Furthermore, research with more than 1300 survivors found that most of those who stayed to defend successfully protected their homes and property (Whittaker et al., 2010). A Royal Commission into the fires concluded that although the fires had exposed weaknesses in the way it was applied, the central tenets of the policy remained sound (Teague et al., 2010). Under the new slogan 'Prepare, Act, Survive', fire and emergency services now emphasise leaving early as the safest option on days of 'catastrophic' fire danger, although residents retain the right to stay and defend their homes and properties. 


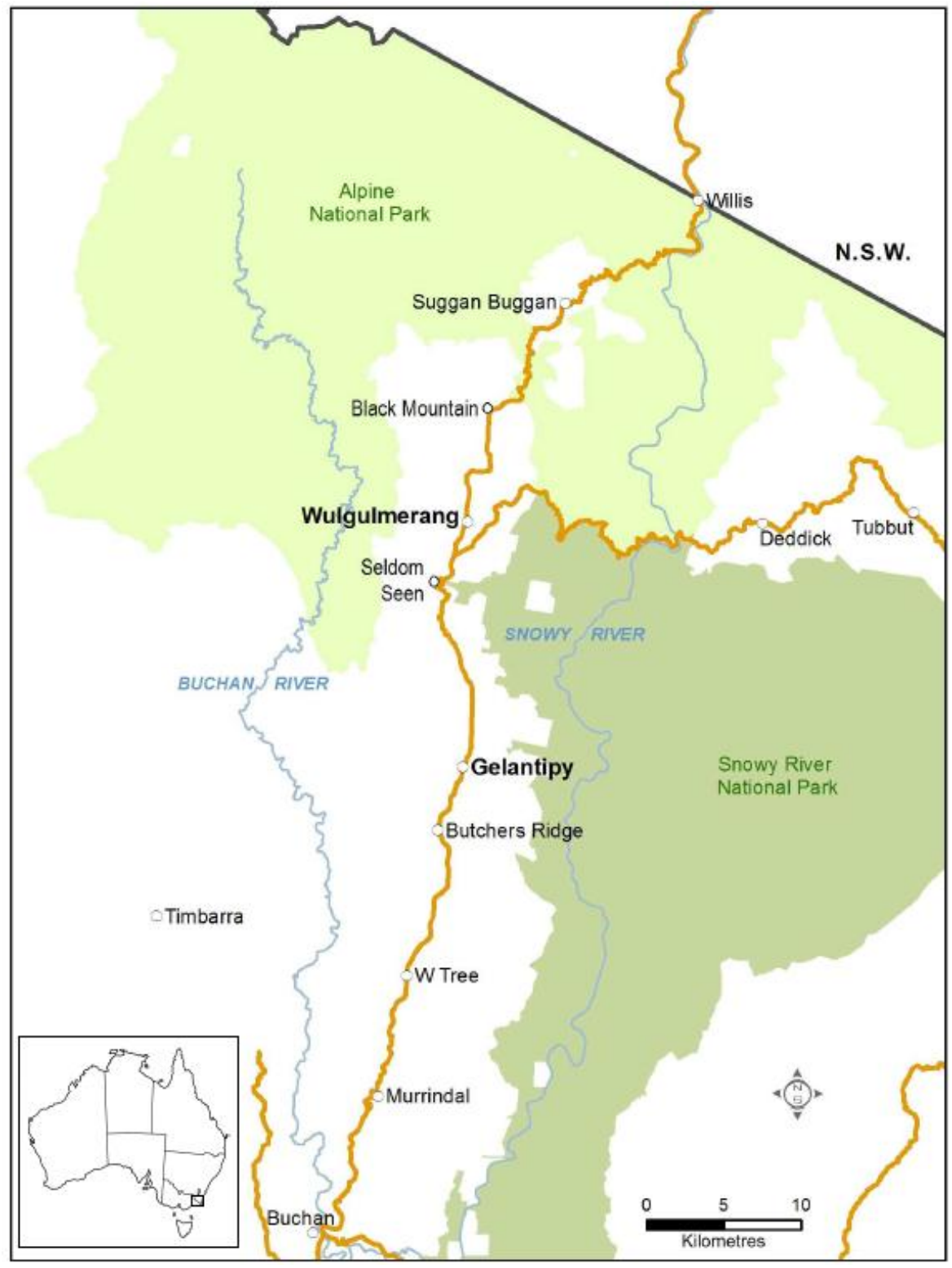

Figure 1: The Wulgulmerang district 
Long-build up Local people had ample forewarning and time to prepare; however, (but rapid extreme weather conditions caused the fires to spread rapidly and arrive spread) earlier than expected.

Spatial extent The fires grew by more than 200,000 ha in the week preceding January 30 and were estimated to have burned 465,000ha of forested land (CFA and DSE 2003; Wareing and Flinn 2003). Consequently, hundreds of communities were threatened and firefighting resources were committed throughout the State.

Simultaneous impact
Fires affected large parts of the district simultaneously. In past fires people were able to move around the district to defend assets. Consequently, people were limited in the support they could provide to neighbours.
Extreme fire behaviour and intensity
The FFDI reached 52 ('Extreme') at Gelantipy and is certain to have been much higher further to the north, where the majority of houses and farm buildings were destroyed. Particularly extreme fire behaviour was experienced as a result of the south-west wind change blowing two runs of fire together. Studies have shown that the probability of house destruction dramatically increases at higher FFDIs (Jasper 1999; Bradstock and Gill 2001).

Table 1: Fire characteristics influencing hazard exposure 


\section{Acknowledgements:}

This paper is based on research undertaken at RMIT University, Melbourne, and funded by the Bushfire Cooperative Research Centre. Thanks are due to: the local people who generously shared their experiences of the disaster and their profound knowledge of the district and its environs; Dr Katharine Haynes for her constructive comments on the manuscript; and the anonymous reviewers. 